\title{
The strategic use of the scope of justice in legitimizing intergroup conflict
}

\author{
Aline Lima-Nunes ${ }^{1}$ \\ Kamila Gadelha Farias ${ }^{2}$ \\ ${ }^{1}$ Universidade Federal de Campina Grande, Campina Grande, PB \\ ${ }^{2}$ Instituto Superior Múltiplo (IESM), Timon, $M A$
}

\begin{abstract}
This study sought to analyze how the scope of justice perception, based on the influence of group position, can be used to legitimize social exclusion. One hundred and three college students aged between 18 and 30 years $(M=20.44 ; S D=1.98)$ participated. The study was composed of two experimental conditions: the participants justified the situation posed by an experimental condition (restriction of the scope of justice) or control (observers) through questionnaires. The content analysis was made from found justifications. The results introduced that, in restriction condition, the legitimization of the hegemonic position from dominant group occurred through meritocratic discourses. In control group, participants perceived social inequality and suggested widening the scope of justice, that is, non-restriction of rights for certain groups. Therefore, the strategic use of arguments of justice is identified as the widening/restriction of the scope of justice to justify social inequalities according to a certain group position.
\end{abstract}

Keywords: scope of justice; legitimation; intergroup conflict

O Uso Estratégico do Escopo de Justiça na Legitimação do Conflito Intergrupal

\section{Resumo}

O presente estudo buscou analisar como a percepção do escopo de justiça, a partir da influência da posição grupal, pode ser utilizada para legitimar a exclusão social. Participaram 103 estudantes universitários com idade entre 18 e 30 anos $(M=20,44$, $D P=1,98)$. O estudo foi composto por duas condições experimentais: os participantes justificavam a situação colocada por uma condição experimental (restrição do escopo de justiça) ou controle (observadores) por meio de questionários. Realizou-se a análise de conteúdo das justificativas encontradas. Os resultados mostraram que, na condição de restrição, aconteceu a legitimação da posição hegemônica do grupo dominante através de discursos meritocráticos. No grupo controle, os participantes percebiam a desigualdade social e sugeriam ampliar o escopo de justiça, ou seja, não-restrição de direitos para determinados grupos. Dessa forma, identifica-se o uso estratégico de argumentos de justiça como a ampliação/restrição do escopo de justiça para justificar as desigualdades sociais de acordo com determinada posição grupal.

Palavras-chave: escopo de justiça, legitimação, conflito intergrupal

\section{Uso estratégico de alcance de justicia en la legitimidad del conflicto intergrupal}

\section{Resumen}

El presente estudio buscó analizar de qué forma la percepción de "alcance de justicia", a partir de la influencia de la posición grupal, puede ser utilizada para legitimar la exclusión social. Participaron 103 estudiantes universitarios con edades entre 18 y 30 años $(M=20.44, D P=1.98)$. El estudio fue compuesto por dos condiciones experimentales: los participantes justificaron la situación planteada por una condición experimental (restricción de "alcance de justicia") y por el control (observadores) por medio de cuestionarios y fue realizado análisis de contenido de las justificaciones encontradas. Los resultados mostraron que, en la condición de restricción sucedió la legitimación de posición hegemónica del grupo dominante a través de discursos meritocráticos. En el grupo control, los participantes percibieron desigualdad social y sugirieron ampliar el alcance de justicia, o sea la no restricción de derechos para determinados grupos. De esta forma, se identificó el uso estratégico de argumentos de justicia como ampliación / restricción de "alcance de justicia" para justificar desigualdades sociales de acuerdo con determinada posición grupal.

Palabras clave: alcance de justicia; legitimidad; conflicto inter-grupal

\section{Introduction}

Social justice is a present objective on the basis of democratic societies and must be ensured as a fundamental right of citizens. Conversely, for certain minority groups (eg., blacks, gypsies, indigenous people), there is a restriction on their access to social justice. Thus, social/racial/gender exclusion in Brazil continues over the years, despite struggle movements and resistance against these discriminatory processes.

Discrimination against certain minorities in Brazil is still a constant. According to Rodrigues (1998 apud Mello, 2005), a study on "cordial racism" in 1995 shows that although $89 \%$ of Brazilians agree that there is prejudice against blacks in Brazil, only $10 \%$ admit some prejudice degree in relation to this group. On 
the other hand, $87 \%$ of the participants agree, admit or pronounce statements or behaviors with prejudiced content. These data present the prejudice dimension in Brazil, in which the vast majority can use veiled forms of prejudice, such as expressions and jokes, and still maintain a fair citizen self image.

In this way, it is questioned why the issues of racial discrimination are invisibilized and disregarded, even seeming to be non-existent? Possibly the answers to these questions correspond to aspects related to three concepts raised in this work: the intergroup relationship, the "scope of justice" and the Justified Discrimination Model (JDM) (Pereira, 2011; Pereira \& Vala, 2010).

The differentiation between certain groups is formed from a belonging sense, as well as through the belief that there are crucial differences between groups, that is, the own group (ingroup) is perceived as more human and less animalistic in relation to another group (outgroup). Through this ethnocentric perspective, groups are characterized by an intrinsic essence and not through circumstances and events, in which certain conceptions are naturalized (Pereira, Vala \& Leyens, 2009; Tajfel, 1970).

At the root of the social exclusion processes exist the intergroup conflict concerning social contexts (eg., Sherif, 1967). Therefore, the intergroup difference itself raises ways of dealing with interest conflicts, sometimes excluding certain rights groups that theoretically should be extended to all (Torres \& Camino, 2013).

According to Pereira, Torres and Almeida (2003), power relations generate ideological representations, which justify discrimination processes against minority groups. Thus, prejudice can be considered as the result of power relations between majority and minority groups, either through the hierarchy belief or the perception that groups should or should not have their rights guaranteed. Recent research show how social inequalities based on prejudiced attitudes can be justified by a legitimation complex process (Costa-Lopes, Dovidio, Pereira, \& Jost, 2013).

Certain theories and theoretical models (Pereira, 2012; Pereira \& Souza, 2016) analyze how legitimation can be a psycho-sociological strategy to explain the psychological tension created by the contrasting motivations of expressing prejudice and, at the same time, being able to maintain the fair citizen self-image. In fact, justifying factors such as: the outgroup perception as threatening to society, with immutable cultural differences and infra-humanization, in the sense of dehumanizing outgroup people (Pereira, Vala \& Leyens,
2009). Justifications and rationalizations that subsidize moral exclusion are difficult to detect (Opotow, 1995). These veiled perceptions are elements that can legitimize support for discriminatory policies against social minorities.

Specifically, the legitimizing role of justice perceptions as the scope of justice restriction (Opotow, 1990; Lima-Nunes, Pereira, \& Correia, 2013a) can be applied to several minority groups discrimination, as a justice argument strategically legitimize the status quo maintenance. Nonetheless, expanding the scope of justice can help integrate these groups as citizens with all rights ensured, so that justice arguments can be used as protective behaviors (Bilewicz, Imhoff \& Drogosz, 2011).

\section{Prejudice, Discrimination and Justice}

Prejudice is strictly related to discriminatory practices and is conceptualized as forms of intergroup relations contextualized by a power relationship, where majority groups develop and express negative attitudes and discriminatory behaviors because members of social minorities participate in those groups (LimaNunes, Lins, Camino, \& Torres, 2010). Stereotypes also have a close relationship with categorizations, as one of the possible consequences of prejudice, functioning as justificatory factors of discrimination (Pereira \& Souza, 2016).

In fact, discrimination and prejudice have an interdependent relationship, because prejudice is related to discriminatory practices (the manifesting prejudice action). This relationship is mediated by non-prejudiced basic justifications in order to enforce discriminatory action, thus prejudice becomes more veiled (Pereira, Vala \& Leyens, 2009). Such mediation takes the restricted vision form of the scope of justice (Lima-Nunes, Pereira, \& Correia, 2013a).

The "scope of justice" (Deustch, 2006; Opotow, 1990; Staub, 1989) is defined in this paper as the perception that justice principles should be applied only to the ingroup (eg. Hafer \& Olson 2003; Olson et al. 2011). There is a dichotomy between outgroup and ingroup, and therefore, the justice principles application to the outgroup must be different from that applied to the ingroup, based on morality incongruities, belief system and the justice principles that mark these groups otherness. Thus, the scope of justice restriction only to the ingroup excludes the justice principles application to outgroup as equality, benefits, resources division, and delimits access to rights to those who are not part of the ingroup (Opotow 1990, 1995). 
Therefore, the scope of justice restriction is the psychological mechanism that lies between prejudice and discrimination. Thus, the greater the prejudice, the greater the need to reduce the scope of justice only to ingroup individuals (Lima-Nunes, Pereira \& Correia, 2013a). The consequence of this restriction may be to favor the ingroup (eg. Tajfel \& Turner, 1979), but it can also be a type of discrimination in other spheres, such as support for discriminatory policies against outgroup (active) or non-support for policies that favor outgroup (passive).

Thus, an explanation for the perpetuation of violence or disregard for certain groups in society may be within the scope of discourses justifying prejudice. The Justified Discrimination Model (JDM) is presented as an explanatory hypothesis in order to explore this issue. Specifically, the JDM examines how, between prejudice and discrimination, there is mediation of a (non-biased) discrimination justification to be understood as fair.

These devices are necessary in societies with egalitarian ideals, when through justifying factors, individuals seek to find a coherence between these ideals and internalized attitudes (Modesto et al., 2017; Pereira, Vala \& Leyens, 2009). In this sense, the answer to the question "Why the restriction perpetuation on the scope of justice is insufficiently fought?" may be the idea that social inequalities are perceived as legitimized and thus the withdrawal of rights is seen as valid.

In this sense, this study referred to the analysis of justice perceptions (eg., the scope of justice) and its role in the process of legitimizing intergroup conflict, that is, how these perceptions can legitimize social inequalities in a Brazilian students population. For that, it was analyzed how the justice arguments are used in the mechanisms implementation directed to social justice, specifically, investigating the scope of justice role and its application in the Brazilian context.

In order to analyze the legitimation forms of this intergroup conflict type, this study aimed to analyze if the scope of justice can be used as a base discourse to interfere in the justice application to depend on social position. That is, to identify whether, according to the group position presented in the situation (dominant or neutral), people use the scope of justice strategically to justify their exclusion intentions or social inclusion.

\section{Method}

In order to analyze the justifying justice role (Lima-Nunes, Pereira \& Correia, 2013b) in the Brazilian context, a qualitative experimental study was designed in order to identify its strategic use in two specific situations: when people are part of the dominant group (situation of intergroup conflict) and when they are merely observers of the conflict (assuming a neutral position).

Thus, it was expected that, in the intergroup conflict presence, people would make use of justificatory discourses to restrict resources only to their belonging group (eg., "racial quota is one way of discriminating whites who have everything on merit without the Brazilian State help”). It was also hoped that, in the intergroup conflict absence, people would broaden the resources use to all possible groups (eg., "racial quota is one way for all, truly, have the same rights to university and work in Brazil").

\section{Participants}

A total of 103 (one hundred and three) university students enrolled in a university in the Paraíba countryside participated in this study. They come from courses in three knowledge fields: human (administration, design and geography), exact (mathematics, materials engineering, mining engineering, production engineering, petroleum engineering and chemical engineering) and biological (nursing) courses. From these participants, 68 reported being female and 35 male. It was a predominantly young sample, with ages ranging from 18 to 30 years $(M=20.44$; $S D=1.98)$, with a people predominance between 18 and 23 years of age, corresponding to $90 \%$ of the respondents.

\section{Procedures}

Before conducting the research, the project was submitted to the Ethics Committee by the Plataforma Brasil (CAAE 47911615.1.0000.5182). By being in agreement with the ethical procedures, it obtained its approval. Participants signed the Free and Informed Consent Term, where the research procedures and doubts were elucidated, praising the respondents anonymity in the questionnaires, with the initiative to make them aware of the process.

\section{Instrument}

The questionnaire was the instrument used to collect data, being composed of sociodemographic issues (sex, age and course) and the problem situation resulting from manipulation. Two questionnaires models were collected, each corresponding to an experimental condition: restriction of the scope of justice and neutral. 
Their distribution was random relative to the experimental condition (restriction or neutral), in which only one of the two conditions was presented to the participants, guaranteeing a greater diversity of responses. The research scenarios were classrooms, in the classes beginning or end, making it difficult to spread.

After reading the problem situation, after any doubts heeded, the participants were summoned to justify their position depending on the experimental condition, writing at least three sentences to do so. The instruction was to write what they thought about their justice perception in that problem situation, and to seek to position themselves from the proposed statement, justifying the situation. In this sense, the conditions were intended to verify the following hypothesis: the participant's group position influences his/her justice perception, and consequently, the scope of justice application.

Both experimental conditions had the same initial information: "We are interested in understanding how our justice perception depends on where we are. So we want you to be part of a hypothetical situation, assuming the role we present below." After this statement, the problem situation corresponding to the experimental condition or control condition was presented.

Condition Restriction of the scope of justice: the statement presented a scenario with the scope of justice restriction, so that the participants justified a position of rights restriction to outgroup without threatening their fair citizen self-image, because it is in the hypothetical situation statement. It is worth mentioning that the dominant group was not named, which would be in charge of the respondent's understanding. The complementary statement of the condition was: "Imagine the following scenario: There is one country where justice is not for everyone because there are dominant groups and dominated groups. You, the participant, are part of the dominant group, with the power to restrict the rights application to be applied more to your group than to the dominated group. How do you, part of the dominant group, justify this difference in the rights application in this country? Write at least three sentences."

Condition Control: the statement also presented a scenario, but the participant should justify his/her response from a neutral position. The idea in this condition was to equate the tasks in the two conditions, that is, to be placed only as an observer, without being part of the context. Thus, the control condition complement to the general statement was: "Imagine the following scenario: There is one country where justice is not for everyone, because there are dominant groups and dominated groups. You, the participant, are neutral and do not make part of either group, being only an observer, without power in the rights application to neither of them. How do you, a neutral party in the situation, justify the rights application in this country? Write at least three sentences. “

The answers analysis was based on Content Analysis, based on Bardin (2011), which is a methodological set applied to a variety of discourses. It is a controlled hermeneutics where deduction is applied, uniting two extremes, both the subjectivity fecundity and the objectivity rigor. The categorizations were elaborated through three stages: pre-analysis, material exploration and results treatment.

\section{Results}

The participants' responses categorization was divided according to experimental conditions in the "dominant group" (condition restriction of the scope of justice) and "neutral group" (control condition). The dominant group condition obtained 50 respondents, while the neutral group condition counted on 53 respondents. Some questionnaires were considered as "unclassified" because they presented answers that deviated from the study purpose or the theme.

In general, the same categories were identified in the two experimental conditions. Differences between conditions are presented from two components: 1) prevalence of a given category in one condition and absence in the other; 2) discursive positioning from the same content (justified social inequality in the restriction condition of the scope of justice is different from justified social inequality in the control/neutral condition).

Subsequently, the categories will be presented according to frequency (in percentage) and, therefore, relevance in the groups derived from the experimental conditions.

\section{Dominant group (the scope of justice condition restriction)}

In this experimental condition, the participants' difficulty arose to position themselves as a dominant group, as requested in the problem situation statement. This effect may have arisen as a criticism from the participants, although some respondents put themselves as "I" and "we" rather than as an external actor to justification. In the responses, the scope of justice retriction based on meritocracy was considered 
the main justification for the difference in the rights application, just as economic inequality was associated with the dominant group existence. A relevant component in the justifications in this experimental condition refers to the meritocratic discourses use to justify their dominant position towards the other group, indicating the effectiveness of the restriction manipulation.

\section{The scope of justice restriction}

The scope of justice restriction was associated with the privileges justification and leadership of the dominant group, and the reasons that enabled this group to gain power. It was also mentioned the favoring of people belonging to the ingroup, in this sense, meritocracy is a crucial justification. This categorization refers to $38 \%$ of the questionnaires with statements from the dominant group.

The dominant group attention is directed towards the ingroup participants and their counterparts, where the outgroup rights are secondary to their own interests, as the following argument illustrates: "It is a right matter, of merit, therefore, while dominant, I believe that my right worths more than the others rigbt'(D35).

The differentiation justification in the rights application is through meritocracy: "The justice application in a differentiated manner can be justified on the merit basis (D47)." This conception is associated with neoliberal ideals, recognizing the individual acquisitions quality, legitimizing through exploitation ideology over a majority and a minority dominating social production (Helal, 2007).

\section{Scope of general justice}

The scope of general justice refers to a justice broader argument, in agreeing with the problem-situation statement, approaching the scope of justice concept itself. In this category, the participants confirm the inconsistencies present in the justice, legitimating the asymmetric power relations. In the scope of justice restriction condition, this category corresponded to $18 \%$ of participants' responses. Here is an example of an answer:

D17: "As a buman being grows in the environment in which society causes you to grow economically, there will always be dominant and dominated classes as the relation employer and employee."

Thus, the legitimation of one subordinate group is presented, where the privilege is perennial for the dominant group, while the rights restriction faced by the dominated group entails a series of losses.

\section{Social inequality}

The social inequality conception is related to the dominant group economic condition, and as one of its consequences, to have impunity and the corrupting justice possibility. Being 18\% of the total restriction condition, this category presents corruption as the main cause of inequality.

The favoring forms of the dominant group refer here to financial status, formal education and high positions: D18: "a dominant group is often responsible for high positions and high purchasing power, for having this set of characteristics linked to higher education for finding loopholes in the laws and being favored by others for passing on an idea that they are the society basis." According to respondents, such privileges carry some advantages, such as supposedly facilitated corruption, favoring inequality in the way the law is enforced and rights enforced.

\section{Individualization}

In this condition, individualization is described as a tendency to associate personality traits with the dominant group superiority, especially characteristics considered negative, such as egoism or "machiavellian traits." This category corresponded to $10 \%$ of the responses found in the experimental condition.

D40: "Differentiated treatment may be a result of the dominant group awareness lack, aiming only for self-improvement. The overlapping of self-will before the will of others shows the justice sense lack and selfishness. "

The justice conception on the part of the dominant group is put as distorted by only favoring the own group, but due to a psychological factor or sense lack. The reflection lack is placed before the effect of their acts on the dominated group, giving the dominant group a purely individual trait.

\section{The scope of justice expansion}

This category, in the restriction condition, refers to the participants difficulty participants to place themselves in the dominant group position. Respondents proposed solutions to reduce inter-group inequality, both towards basic education and fundamentally through justice, that can reach all people, that is, widen the scope of justice for the outgroup people. Only $10 \%$ of participants responded according to this category.

D26: "There is no way to do justice if a portion or group of this imaginary country has fewer rights than others. Therefore the real way to do justice is in the rights application for all without distinction of color, race, financial condition or social status (...)”. 
This type of discourse is agrees with what Helal (2007) indicates about education and the merit perspective. When education is related to a leveling inequality model, it puts the individual in charge of the society transformation, which is part of a meritocratic vision. On the other hand, education can be seen from this point of view of a factor that maintains social inequalities and, thus, is fundamental for social stratification.

\section{Mobilization lack}

The tone of the mobilization lack category follows the disinterest direction, conformation and even passivity of the dominated group, as a possible way to blame this group. However, the mobilization is considered in these justifications as preponderant to change the dominated group condition, guaranteeing rights extension. This category represents $6 \%$ of the responses from the dominant group condition.

D43: "I believe that the difference in the rights application has been present for a long time in this country, and that the population is conformed to this situation and does not mobilize to modify this type of thing."

\section{Neutral group (control condition)}

In this condition, the category "social inequality" has been highlighted, related to nepotism, corruption and power, in a similar way the dominant group, but tending to name those who participate in the dominant and dominated groups. There were also speeches related to the scope of justice expansion, that is, the rights application for all, equally distributed. Due to the participant's position as an observer, as requested by the experimental condition, it was possible to give visibility to the specific issues of certain struggles (racial, ethnic and sexual orientation issues), illustrated in excerpts from the participants' justifications.

\section{Social inequality}

In this experimental condition, the financial condition presents itself as an interference for the proper rights application and/or compliance with the law. About half of the respondents $(40 \%)$ in the neutral group justified the problem situation through the difference in law enforcement.

N34: “(...) People with greater purchasing power, those with influential relatives and/ or friends became 'participants in dominant groups'. And the rest of society ends up being 'the dominated group', being subject to any decision of the dominant group. Law enforcement is for everyone, but 'dominant groups' are those who end up being left out, because their social condition 'sets them apart' from others. We have, for example, these groups: politicians, judges, police..."

In the aforementioned answer, the fact that, through friendship or some family bond, to live with people with high purchasing power, is already a way of entering the dominant group, and thus, obtain privileges. Other determining factors for the rights application are placed beyond the financial question, such as the ethnic question, considered as a factor of intergroup inequalities. The racial difference is put in some answers as the intergroup difference justification, just as the gender difference and sexual orientation, in this neutral category, it is named which groups are more disadvantaged than others.

\section{Scope of general justice}

This category was relevant in the control condition, once $28 \%$ of the responses of this condition fit within it. Some discourses are based on the justice questioning, which tends to provide the right for few and even unworthy means, either through corruption or with the oppressing purpose and securing the power that its position reserves. Here's an example of this argument:

N38: "It is natural that in a country where the laws are written by a certain group that has been in power for some time, this group is always interested in the privileges maintenance guaranteed by that power. On the other hand, it is becoming increasingly difficult for the oppressed group to break these barriers, since it is necessary to be in power to guarantee rights."

Thus, a dichotomy between practice and theory in the justice application is evident, because the law is not at the good service for all regardless of the group position in which they are. However, in order to assert power over the dominated group and as a mode of control, the laws drafting are on the dominant group hands, retaining the privileges to aim for its own good.

\section{The scope of justice expansion}

Respondents have evoked a trend towards the ingroup rights application to the outgroup for allinclusive justice. Another positioning form refers to the end of the differentiation between dominated and dominant group, through the search of a repair to the dominated group, with the purpose of guaranteeing the equal justice for all, an example concerns the quotas. This category corresponds to $22 \%$ of the neutral group's answers.

N52: "The application of rights in this country occurs in the wrong way, because, as neutral, I take position thinking 
that there should be no dominant and dominated groups. Everyone should have equal rights, both before men and before justice. Accordingly, improvements should be made in groups of politicians to improve equality of justice between groups."

The scope of justice extension in this section is proposed through the political reform possibility to achieve equal rights for each other and for justice. Therefore, the discourse in this fragment considers the transformation power being exclusively in charge of the political class, that is, of the dominant group. Politics also depends on popular participation, through claims, as well as politicians are elected by a population, which still has a certain choice power.

\section{Lack of mobilization}

This category lists justifications that express a conformation of the dominated groups in not claiming their rights for the justice application, either because they have a knowledge lack of their rights or because there are no claims movements. This category is related to about $6 \%$ of justifications.

N36: "And on the other hand the dominated go to the streets to claim what they want, but the fact of having no degree of kinship with people of powers lose their voice, but they claim and in some cases they are heard."

The dominated group invisibility and, because of this, influence and voice lack are placed as factors that make it impossible to perceive this group demands, that is, own belonging to the dominated group would be an exclusion factor because they did not have access to outgroup. However, their demands can be met due to the mobilization, considered a fundamental factor for the representativeness effectiveness and the rights guarantee.

\section{Individualization}

This category has as main point to attribute personality characteristics and affections to dominant group members. There is an exclusion of the social question in these discourses, possibly in an attempt to minimize the intergroup conflicts consequences existing in the scenario. It would be an attempt to hold each subject responsible in the relationship, for it shifts the action of a dominant abstract group to the individual plane. This category corresponds to approximately $4 \%$ of the questionnaires.

N37: "I believe that the rights difference in whatever the locality does not start from the dominant group action, but part of the individual action of each person contained in the dominant group. The rights struggle must reach the field of equality: considering, each individual is entirely equal to others."

\section{Discussion}

The results point to the existence of the strategic use of the justice arguments (scope of justice) to justify the inequality posed in the problem situation. The group position, manipulated from the experimental conditions, influenced the emergence of certain contents to the detriment of others, and consequently, discursive categories.

The categories variety that have arisen in response to experimental conditions show the perceptions plurality even when a specific situation exists. The way the situation is justified illustrates a differentiated perspective on what justice is for everyone. Thus, the arguments that emerged represent relevant justice perceptions from a place in society, posited in the present study as a hypothetical situation, in an unequal country.

In general, different justifying arguments have emerged to depend on position in intergroup conflict. For example, in the neutral group, there were no respondents whose response was categorized as "the scope of justice restriction", while the category "social inequality" emerges as the main justification for the difference in the rights application in this experimental condition. That is, the problem situation, posed from a group positioning, caused the justice perception to be changed, changing the narrative justification focus.

However, in relation to the dominant group condition, the category "the scope of justice restriction" stood out among others, with a greater occurrence, while the category "social inequality" was less prominent. The "restriction of the scope of justice" category emergence in this condition may be related to an ingroup favoring, due to the dominant group social prestige, since the outgroup rights should be restricted (Tajfel \& Turner, 1979).

As expected, the most relevant results refer to the scope of justice restriction condition (dominant group), where a greater occurrence was obtained regarding justification of the justice application restricted to the ingroup. Specifically, the justification for the dominant and dominated group position argues, through meritocratic discourses, the resources restriction to the dominated group.

The belief in meritocracy as a descriptive norm makes it possible to support and sustain various discrimination forms and inequality maintenance, but 
it depends on whether the context has norms with egalitarian values. Meritocracy can be motivated by discrimination (eg., racism), by perceiving that individuals (eg., blacks) are responsible for their own social position, where this merit idea is a legitimating discourse that mediates racism and opposition to affirmative action, considered to be unfair for opposing the merit idea (Pereira, 2012, Pereira \& Souza, 2016).

In the scope of the present study, even when faced with a hypothetical situation, the discursive pattern follows a legitimizing logic to the superiority of one group over others. That is, even if "real groups" are not identified, the group positioning has influenced the psychological process that underlies the justification based on a justice perception. Such a mechanism reinforces the asymmetrical relationship of power that was presented, by the argument characteristic - justification by justice. In this sense, the Justified Discrimination Model premise (JDM, Pereira, 2011) can be applied to the process identified in the discourse based on justice arguments, where the group effect position on the differentiation behavior is not direct, but mediated by the scope of justice restriction.

Therefore, when the participant was summoned to position himself/herself as part of a dominant group in the hypothetical situation, the arguments used to justify the restriction of resources were: the status quo maintenance and the position it occupies in society. While in the observer position (neutral position), the justifications were to give visibility to groups that suffer social exclusion and the attempt to seek equitable justice. These results corroborate studies that point to the scope of justice restriction as an effective social exclusion justification, showing how justice arguments can help in the derogation of certain groups (Coryn \& Borshuk, 2006, Kals, \& Strubel, 2017; Lima-Nunes, Pereira, \& Correia, 2013b).

In this sense, the scope of justice strategic use concerns the restriction application to the problem situation, justifying the group positioning, starting from the respondent situational perception. Thus, the restriction application of the scope of justice to the ingroup occurs because such an argument seems "reasonable and appropriate (from the actor's point of view) to accept passively or even to contribute to the one individual suffering and not of another." (Hafer \& Olson, 2003, p 321).

Conversely, when the condition is neutral, the participants argue their position of observer, pointing out the social inequality arising from the separation of groups between dominant and dominated. Moreover, in this experimental condition, the participants present greater occurrence of content related to the scope of justice expansion, that is, $22 \%$ of the arguments in the neutral condition to the detriment of $10 \%$ of the arguments in the restriction condition. That is, when the group position was not directly influencing participants' perception of the problem situation, the possibility of allowing the rights application to be extended to all groups seems more feasible.

\section{Final considerations}

The arguments existence based on justice perceptions make possible to deepen the scope of justice role in discriminating against certain minority groups, supporting previous research on the subject (eg., Hadarics \& Kende, 2018; Lima-Nunes, Pereira, \& Correia, 2013a).

Field research is fundamental to broaden the horizons of theoretical development, thus finding empirical evidence of the hypotheses discussed in this paper. Although the scope of justice strategic use in legitimizing arguments of intergroup conflict has been identified, some methodological limitations of the study should be pointed out. On the one hand, the exploratory and qualitative character of the present study made possible to access the psychological mechanism of scope of justice restricting in a broader and more complex way, corresponding to the construct itself.

On the other hand, the subjective response to the manipulated problem situation made it difficult to differentiate between experimental conditions, with similar categories in the two conditions. The main difference between the conditions was identified in the category that presented only in the dominant group condition: the scope of justice restriction by meritocracy.

Likewise, we identify the limitation when responding to the dominant condition (the scope of justice restriction). Participants hesitated to justify their position, and there was a difficulty in naming who would be responsible for restricting the rights application. This hesitation was understood as an attempt to avoid a possible ingroup blame and the responsibility induced by the manipulation. This inability may be related to a mechanism concerning cognitive dissociation where people tend to deny that they are prejudiced by imputizing prejudice to an abstraction or even, in the present case, avoiding being held accountable (Pereira, Torres \& Almeida, 2003). 
In relation to the control condition (neutral group), it was easier to name the actors in each group and the justice restriction due to the participant position as an observer. In fact, the justification most present in this second group is social inequality, followed by the scope of general justice and the scope of justice expansion, which in the dominant group did not appear as more relevant discourses. Despite the neutrality requested by the problem-situation in this experimental condition, such positioning in reality is impossible. Thus, the attempt to place itself in this position may have generated an artificiality in the arguments to justify the difference in the rights application.

In general, in order to resolve such limitations, by facilitating the differentiation between experimental conditions, quantitative studies using measures already developed to measure the scope of justice are needed (eg, Scale of Scope of Justice, Lima-Nunes, Pereira, \& Correia, 2013a).

In order to face discrimination, the struggle for the rights achievement must be constant, since the perpetuation forms of discrimination become more rooted and intricate (Pereira, Vala \& Leyens, 2009). The reconfiguration in the occupation of the public spaces and the social ascension opportunity are being conquered, leading to the composition of a more egalitarian society.

In this perspective, the scope of justice strategic use can act both to prevent the general development of social justice, facilitating segregation (restricting the scope of justice), as well as stimulating cooperation between groups, allowing for greater openness of justice to other groups (widening the scope of justice). Thus, the scope of justice strategic use depends on what position the subject occupies in the intergroup relationship.

Thus, this study constitutes as an advance in the Brazilian literature in the social psychology of justice scope, for addressing the scope of justice in relation to the group context. It is hoped that this research can serve as a basis for the development of a research line that relates the justice perception to aspects related to intergroup relations. The fact of perceiving the justice application as (a) restricted to certain groups or (b) extended to many or all groups can have great effects on the derogation of historically minority groups, with great difficulties in conquering rights. Future studies should explore the relationship between the scope of justice and specific forms of prejudice and discrimination, as well as seek the validation of the scale of the scope of justice in Brazil.

\section{References}

Bardin, L. (2011). Análise de conteúdo. São Paulo: Edições 70. $229 \mathrm{p}$.

Bilewics, M., Imhoff, R., \& Drogosz, M. (2011). The humanity of what we eat: Conceptions of human uniqueness among vegetarians and omnivores. European Journal of Social Psychology, 41, 201-209. doi: 10.1002/ejsp.766

Coryn, C. L. S., \& Borshuk, C. (2006). The scope of justice for muslim Americans: Moral exclusion in the aftermath of 9/11. The Qualitative Report, 11, 568-604. Retrieved from http://nsuworks.nova. $\mathrm{edu} / \mathrm{tqr} / \mathrm{vol11} /$ iss3/9

Costa-Lopes, R., Dovidio, J. F., Pereira, C., \& Jost, J. T. (2013). Social psychological perspectives on the legitimation of social inequality: Past, present and future. European Journal of Social Psychology, 43(4), 229-237. doi: 10.1002/ ejsp.1966

Deutsch, M. (2006) Justice and conflict. In M. Deutsch, P. T. Coleman, \& E. C. Marcus (Eds.), The handbook of conflict resolution. San Francisco, CA: Jossey-Bass, $2^{\text {nd }}$ Edition. p. 41-64. doi: 10.1007/978-1-4419-9994-8_5

Hadarics, M., \& Kende, A. (2018). Moral foundations of positive and negative intergroup behaviour: Moral exclusion fills the gap. International Journal of Intercultural Relations, 64, 67-76. doi: 10.1016/j. ijintrel.2018.03.006

Hafer, C. L., \& Olson, J. M. (2003). An Analysis of Empirical Research on the Scope of Justice. Personality and Social Psychology Review, 7, 311-323. doi: 10.1207/s15327957pspr0704_04

Helal, D. H. (2007) O papel da educação na sociedade e organizações modernas: criticando a meritocracia. Revista Eletrônica de Administração, 13(2), 386-408. Retrieved from http://seer.ufrgs.br/index.php/ $\mathrm{read} / \mathrm{article} / \mathrm{view} / 39926 / 25461$

Kals, E., \& Strubel, I. T. (2017). Volunteering to Support Refugees: A Question of One's Scope of Justice. Refuge, 33(2), 66-77. Retrieved from https://refuge.journals.yorku.ca/index.php/refuge/article/ viewFile/40459/36462

Lima-Nunes, A., Pereira, C. R., \& Correia, I. (2013a) Restricting the scope of justice to justify discrimination: The role played by justice perceptions in 
discrimination against immigrants. European Journal of Social Psychology, 43, 627-636. doi: 10.1002/ ejsp.1981

Lima-Nunes, A., Pereira, C. R., \& Correia, I. (2013b). Justice seems not to be for all! Exploring the Scope of Justice. In-Mind Magazine (Holanda), 17, 1-6. Retrieved from http://www.ics.ul.pt/rdonweb-docs/ ICS_CRPereira_Justice_ARI.pdf

Lima-Nunes, A. V., Lins, S., Camino, L., \& Torres, A. (2010). Social insertion and racial prejudice: Distance from black people and socio-political variables. Portuguese Journal of Social Science, 9(1), 3-17. Retrieved from https://repositorio-aberto. up.pt/bitstream/10216/87596/2/158889.pdf

Mello, L. G. (2005). A discriminação racial em números e palavras: um estudo sobre a participação de negros e brancos no mercado de trabalho gaúcho. (Dissertação de Mestrado). Universidade Federal do Rio Grande do Sul (UFRGS), Porto Alegre, RS. Retrieved from http://hdl.handle.net/10183/5186.

Modesto, J. G. et al. (2017). Racismo e Políticas Afirmativas: Evidências do Modelo da Discriminação Justificada. Psicologia: Teoria e Pesquisa., 33, 1-8. doi: 10.1590/0102.3772e3353.

Olson, J. M et al. (2011) Distinguishing two meanings of moral exclusion: exclusion from moral principles or principled harm-doing? Social Justice Research, 24, 365-390. doi: 10.1007/s11211-011-0141-8

Opotow, S. (1990) Moral exclusion and injustice: An introduction. Journal of Social Issues, 46, 1-20. doi: 10.1111/j.1540-4560.1990.tb00268.x

Opotow, S. (1995). Drawing the line: Social categorization, moral exclusion, and the scope of justice. In B. B. Bunker \& J. Z. Rubin (Eds.), Conflict, cooperation, and justice (pp. 347-369). San Francisco: Jossey-Bass.

Pereira, C. R. (2011). A legitimação da discriminação em diferentes contextos normativos. In E. M. Techio \& M. E. O. Lima (Eds.), Cultura e produção das diferenças: Estereótipos e preconceito no Brasil, Espanha e Portugal (pp. 363-404). Brasília: Technopolotik.

Pereira, C. R. (2012). Normas sociais e legitimação da discriminação. In C. R. Pereira \& R. Costa-Lopes
(Eds.), Normas, atitudes e comportamentos sociais (pp. 171-207). Lisboa: Imprensa de Ciências Sociais. Retrieved from http://repositorio.ul.pt/ handle/10451/20549

Pereira, C. R., \& Vala, J. (2010). Do preconceito à discriminação justificada. In-Mind_Português, 1, 1-13. Retrieved from http://www.ics.ul.pt/rdonweb-docs/ CiceroPereira_JorgeVala_2010_n1.pdf

Pereira, C. R., \& Souza, L. E. C. (2016). Fatores Legitimadores da Discriminação: Uma Revisão Teórica. Psicologia: Teoria e Pesquisa, 32(2), 1-10. doi: 10.1590/0102-3772e322222

Pereira, C., Torres, A. R. R., \& Almeida, S. T. (2003). Um Estudo do Preconceito na Perspectiva das Representações Sociais: Análise da Influência de um Discurso Justificador da Discriminação no Preconceito Racial. Psicologia: Reflexão e Crítica, 16(1). 95-107. doi: 10.1590/s0102-79722003000100010

Pereira, C., Vala, J., \& Leyens, J.-P. (2009). From infrahumanization to discrimination: The mediation of symbolic threat needs egalitarian norms. Journal of Experimental Social Psychology, 45, 336-344. doi: 10.1016/j.jesp.2008.10.010

Sherif, M. (1967) Social interaction: processes and products. Chicago: Aldine. doi: 10.2307/144927

Staub, E. (1989) The roots of evil: Origins of genocide and other group violence. New York: Cambridge University Press.

Tajfel, H. (1970). Experiments in intergroup discrimination. Scientific American, 223, 96-102.

Tajfel, H., \& Turner, J. C. (1979) An integrative theory of intergroup conflict. In W. G. Austin \& S. Worchel (Eds.), The social psychology of intergroup relations, Monterey, CA: Brooks/Cole. p. 33-47

Torres, A. R. R., \& Camino, L. (2013). Grupos sociais, relações intergrupais e identidade social. In: L. Camino et al. (Eds.), Psicologia Social: temas e teorias ( $2^{a}$ ed.), revista e ampliada. p. 513-538. Brasília: TechnoPolitik.

Recebido em: 23/05/2018

Reformulado em: 30/07/2018

Aprovado em: 29/08/2018 
Nota das autoras:

This research was funded by CNPq within the framework of the PIBIC/UFCG Grant awarded to the second author.

Sobre as autoras:

Aline Lima-Nunes, Adjunct Professor at Universidade Federal de Campina Grande (UFCG). PhD in Psychology from Instituto Universitário de Lisboa (ISCTE-IUL), Portugal. Master's in Social Psychology from UFPB. Bachelor's and Licentiate degrees in Psychology from UFPB. Researcher in the area of Social Psychology of Justice and Social Exclusion Processes.

ORCID: https://orcid.org/0000-0002-3042-5451

Email: limanunes.aline@gmail.com

Kamila Gadelha Farias, Graduated in Psychology at Universidade Federal de Campina Grande (UFCG). Holds a Post-graduation in Mental Health and Psychosocial Care Network by IESM (Instituto Superior Mútiplo). Researches include themes relevant to Social Psychology and Health, mainly in the scope of public policies related to political minorities.

ORCID: https://orcid.org/0000-0002-5199-838X

Email:kamila.gd@live.com

Contato com os autores:

Aline Lima-Nunes

Universidade Federal de Campina Grande (UFCG), Academic Unit of Psychology

Rua Juvêncio Arruda, 795, Bodocongó

Campina Grande-PB, Brazil

CEP: 58429-600

Institutional email: aline.nunes@ufcg.edu.br 